${ }^{\odot}$ Entomologica Fennica. 3 July 2002

\title{
A new species of deathwatch beetle (Coleoptera: Anobiidae) discovered in Europe
}

\author{
Boris Büche \& Stig Lundberg
}

Büche, B. \& Lundberg, S. 2002: A new species of deathwatch beetle (Coleoptera: Anobiidae) discovered in Europe. — Entomol. Fennica 13: 79_ 84.

A new species of the genus Dorcatoma Herbst (Coleoptera: Anobiidae) is described based on material from Latvia and Sweden, and recorded also for Poland. Dorcatoma janssoni n. sp. is very close in appearance to $D$. chrysomelina Sturm, but male genitalia and biology are different. Antennae and male and female genitalia are figured, and the biology of the new species is described. Dorcatoma ambjoerni Baranowski is removed from the synonymy of $D$. setosella Mulsant \& Rey. A key is provided for the European species of the Dorcatoma chrysomelina-group.

Boris Büche, clo Kaltenbacher, Hasenheide 91, 10967 Berlin, Germany; E-mail:h0444la3@student.hu-berlin.de Stig Lundberg, Rektorsgatan 5, 97242 Luleå, Sweden

Received 31 January 2001, accepted 27 August 2001

\section{Introduction}

The members of the genus Dorcatoma Herbst, 1792, are small to medium sized fungivorous anobiids. Twenty-two species and three subspecies are known from the Palearctic Region, while five species occur in North America (White 1966). Another thirty-two species placed in the genus are known from other regions. All tropical species so far revised have been placed in different genera (Español 1977). The palaearctic species of Dorcatoma have recently been examined by Baranowski (1985), Español (1978), Hayashi (1954), and Logvinowskij (1980). Five species were described within the last two decades (Baranowski 1985, Zahradnik 1993, 1996, 1998, Büche 2001).

Specimens belonging to the genus Dorcatoma, caught with window traps in Latvia and Sweden, were submitted to the authors for determination.
The collectors' assumption that some of these may represent an unknown species was confirmed. The species, dedicated to Nicklas Jansson, who first suspected the identity of his specimens, is described below.

\section{Description}

\section{Dorcatoma janssoni sp. n.}

Body. 1.92 to $2.67 \mathrm{~mm}$ long (head excluded), dark piceous to black. Labial and maxillary palpi testaceous, legs and antennae rufotestaceous; the first, also sometimes terminal three segments of the antennae slightly darker. Punctation of body fine, dorsal surface shining or slightly dull due to microsculpture. Pubescence yellowish, moderately long, erect on dorsal surface.

Head and pronotum. With semierect pubes- 

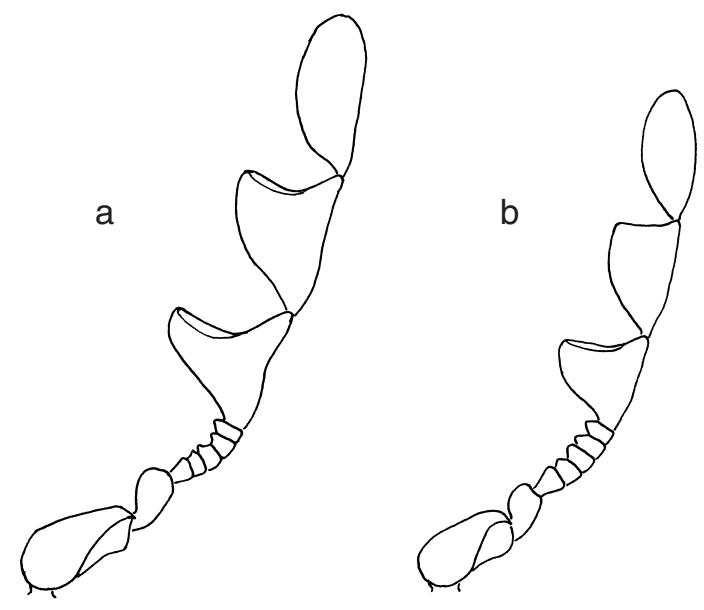

Fig. 1. Dorcatoma janssoni sp. n. - a. Right antenna of male. - b. Right antenna of female.

cence. Hairs between the eyes inclined more or less to the median line, except in middle and on sides, where they are inclined forwards. Pronotum with hairs inclined anteriorly and to side margins. Antennae ten-segmented and of different size and shape between sexes (Fig.1a,b). Last three segments combined in male about $0.6(0.58-0.62)$, in female about $0.48(0.46-0.5)$ times as long as the width of pronotum. Punctation on head and pronotum consisting of punctures of different size, moderate in density, punctures at least their diameter apart on the pronotum, less so on head.

Elytra. Widest in middle, about 1.26 (1.2-1.34) times as long as wide (scutellum included), laterally with three striae each. Lateral and sublateral striae, extending from base to close to suture, are parallel to side margins for most of their length; sublateral striae slightly curved inwards apically. Subhumeral striae short, only visible in basal third to basal half of elytra, not as deeply impressed as the complete striae and often interrupted or dissolved to series of puncture-like impressions. Punctation on the elytra clearly dual, composed of larger, elliptical punctures which are 1.3 times as long as wide, mixed with fine, circular punctures. Diameter of the latter is about onethird to half the longitudinal diameter of the former. Distances between punctures on the elytral disk varying rather widely; in most specimens, larger punctures are about their diameter apart. Punctation denser and punctures more circular

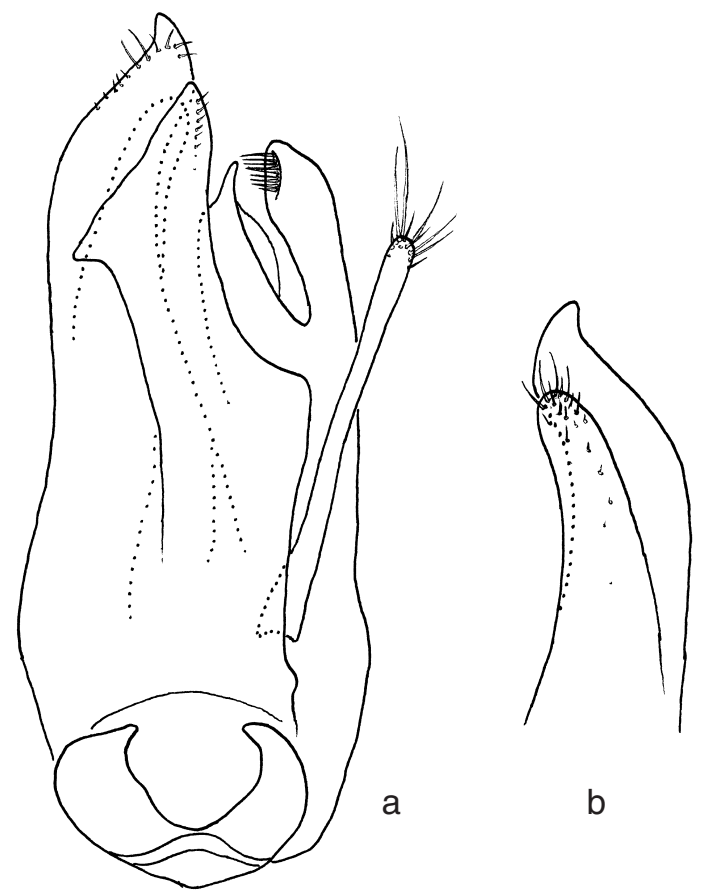

Fig. 2. Dorcatoma janssoni sp. n. - a. Aedeagus, dorsal view. - b. Right lobe from ventral view.

near base and on apex. Sutural area with punctures always connected by fine, longitudinal wrinkles; this microsculpture may be seen on the whole elytral disk in some specimens. Pubescence on elytra erect, consisting of hairs inclined backwards mixed with hairs inclined sidewards. Both hair types evenly distributed.

Ventral surface. With recumbent pubescence and dual punctation that is denser and slightly coarser than on dorsal surface; larger punctures circular and separated by about their diameter. Median furrow of the metasternum beginning with a deep, elliptical pit in the anterior third, becoming shallower posteriorly and continued by a well impressed (rarely interrupted) line in the posterior third. Larger punctures on metasternum absent in a transverse area above the metacoxal plates. Posterior margins of the abdominal sternites almost straight. Male: aedeagus: Fig.2a. Right lobe of the aedeagus with a ventral appendage (Fig.2b). Female: ovipositor elongate (Fig.3), a little more than half as long as the elytra. Body and antennal proportions were compiled from ten males and females each, including the smallest 
and the largest specimen.

Unusual variation. In two specimens of the type series, one or both antennae have only nine segments due to fusion. Reversal of male genitalia, leading to a mirror-image orientation of the lobes, is observed in three specimens of the type series.

Type material. Holotype: Latvia, Slitere Nature Reserve, Blue Hills, window trap 9, 07.VII.1997, leg. N. Jansson/[red label] Holotypus male [symbol], Dorcatoma janssoni sp. n., Büche \& Lundberg desig. 2000. Paratypes: 29 males and 39 females with data on labels as follows: Same as holotype (3 specimens); Latvia, Slitere Nature Reserve, Blue Hills, window trap 10, 07.VII.1997, leg. N. Jansson (1 specimen); Latvia, Slitere Nature Reserve, Blue Hills, window trap 11, 11.VIII.1997, leg. N. Jansson (2 specimens); Latvia, Slitere Nature Reserve, Beaverdam, window trap 4, 25.VII.1997, leg. N. Jansson (2 specimens); Latvia, Slitere Nature Reserve, Beaverdam, window trap 6, 25.VII.1997, leg. N. Jansson (3 specimens); Latvia, Slitere Nature Reserve, Beaverdam, window trap 10, 25.VII.1997, leg. N. Jansson (1 specimen); Latvia, Slitere Nature Reserve, Beaverdam, window trap 4, 20.VIII.1997, leg. N. Jansson (1 specimen); Sweden, Uppland, Hallsboön [in Tierp parish], Lindlåga 07. [= July] 1998, leg. P. Eriksson (1 specimen); Sweden, Uppland, Ekeby s:n [= parish], Svalmyra, granhögstubbe, window trap 07. 1999, leg P. Eriksson (41 specimens); Sweden, Uppland, Ekeby s:n, Svalmyra, in wood of spruce, 12.VI.2000, leg S. Lundberg (6 specimens); Sweden, Uppland, Harg s:n, Kodödkärr, björkhögstubbe, in wood as imago, 11.VI.2000, leg. B. Ehnström (5 specimens); Sweden, Uppland, Harg s:n, Kodödkärr, björkhögstubbe, in wood as imago, 11.VI.2000, leg. S. Lundberg (2 specimens); Sweden, Uppland, Harg s:n, Snöbottenkärret, björkhögstubbe, in wood as pupa, 23.V.2000, leg. H. Wallin (2 specimens).

All paratypes bear a red label with: Paratypus (sex symbol), Dorcatoma janssoni sp. n., Büche \& Lundberg desig. 2000.

The holotype and three paratypes are in the collection of the Riksmuseum, Stockholm. The type locality, Slitere Nature Reserve, is in the extreme Northwest of Latvia; the Swedish localities in Ekeby and Hark parish are northeast of Lake Vällen.

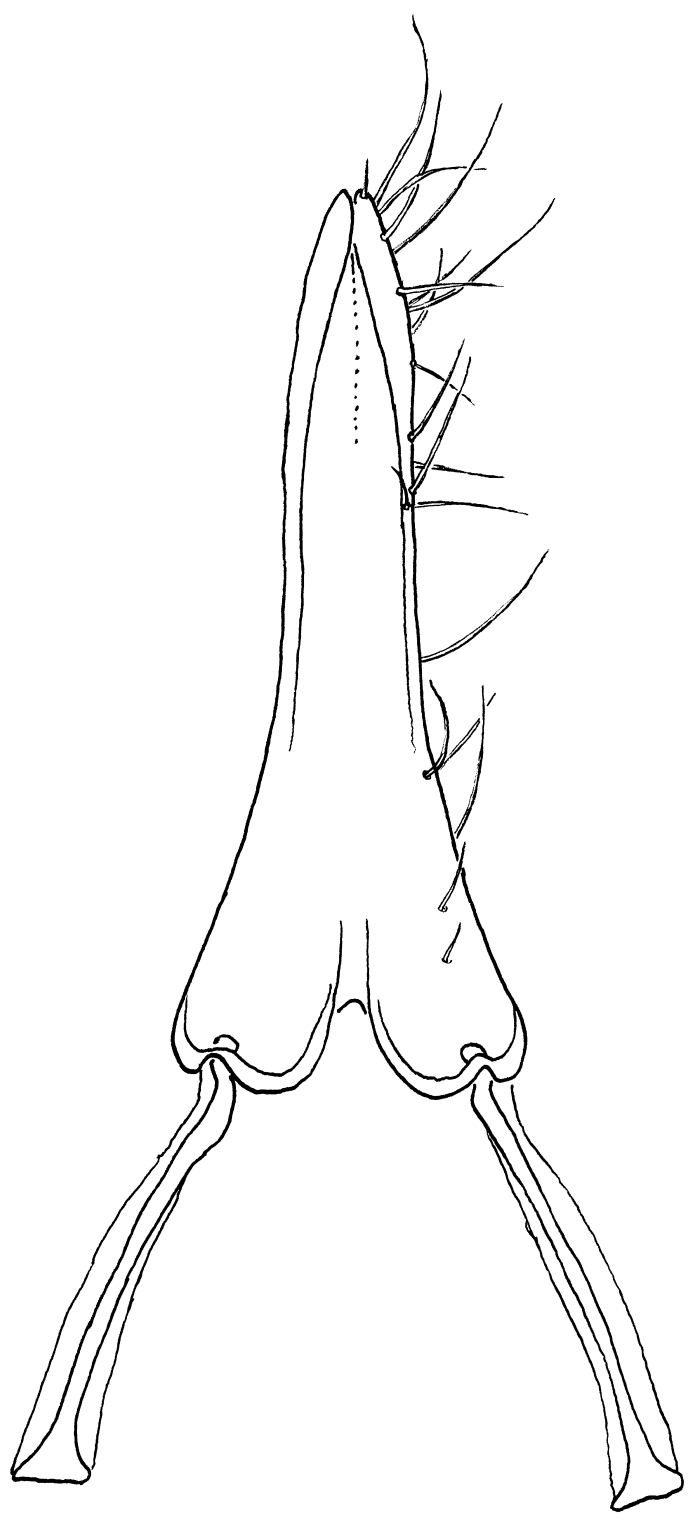

Fig. 3. Dorcatoma janssoni sp. n. Ovipositor, ventral view, setae omitted on left side.

\section{Differential diagnosis}

Dorcatoma janssoni possesses all generic characters pointed out by Español (1977) and is very similar to D. chrysomelina Sturm, 1837, in external characters. Only males are easily separated by the different structure of their copulatory organs. In D. janssoni, punctures on the elytra are smaller and more distant from each other, the 
microsculpture is weaker, and the body is a little stouter on average than in D. chrysomelina. A slight, but constant difference in antennal proportions is found in the males: The length of the three terminal segments averages 0.71 (0.69-0.75; $\mathrm{n}=10$ ) the width of the pronotum in $D$. chrysomelina, compared to $0.58-0.62$ in $D$. janssoni. The valves of the ovipositor are about 1.8 times as long as the apophyses in D. janssoni; in $D$. chrysomelina, the ovipositor is slightly shorter, the valves of the ovipositor are about 1.6 times as long as the apophyses. Only two females of each species were studied in this respect, though. The male genitalia of $D$. janssoni and $D$. setosella Mulsant \& Rey, 1864, are very alike, but the latter species is quite different in general appearance and biology (Neumann \& Büche 1998). From other similar species, D. janssoni may be discriminated by characters used in the key below.

\section{Taxonomic and distribution notes}

Recently, the subgenus Pilosodorcatoma was erected for the group of species to which $D$. janssoni belongs (Borowski 1999). This category is not adopted here, because its defining attributes, ten-segmented antennae and erect pubescence, have not been demonstrated to be synapomorphic. In the same work, D. ambjoerni Baranowski, 1985 , is treated as a synonym of D. setosella Mulsant \& Rey, 1864. Neither an explanation is given to support that taxonomic change, nor was the type material studied.

The description of $D$. setosella is very detailed and allows safe recognition. The reference to subfasciate pubescence on the elytra excludes all European species except D. minor Zahradnik, 1993. Several points in the description (punctation, shape of body and antennal segments) indicate, that material of D. minor was not in the hands of Mulsant and Rey.

A syntype of $D$. ambjoerni was compared with abundant material of $D$. setosella, fully agreeing with the original description, and also with the interpretation of later authors. The comparison has clearly shown that the two species are not the same; D. ambjoerni is species propria. Descriptive notes and illustrations (including aedeagus) in Borowski (1999) show that D. setosella sensu Borowski actually is D. janssoni. The male genitalia of all three species show certain affinities, the most remarkable being the presence of a ventral appendage at the right lobe. Such is not found in any other European species and is perhaps a synapomorphy.

Dorcatoma janssoni is stated as being widespread in Poland (Borowski 1999); five localities in the southern and eastern parts of the country are given. D. janssoni probably has a rather wide distribution in Europe.

\section{Biology}

Like other members of the genus Dorcatoma, $D$. janssoni is a saproxylic and mycetobiont species. In Sweden, larvae, pupae and imagines of $D$. janssoni have been found in three localities in standing, dead trunks of spruce (Picea abies) and birch (Betula pendula), infested by the fungus Fomitopsis pinicola. The larvae develop in dense aggregations in outer parts of the wood, slightly softened by the fungus mycelia, up to $5 \mathrm{~cm}$ below the surface. The larvae were preferably occurring in portions of the trunks, where the bark has fallen off. The condition of the wood is the same as requested by the peltid beetle Peltis grossa. This species was also found together with Dorcatoma janssoni. Fruiting bodies of $F$. pinicola, when present, were colonized only by Dorcatoma punctulata Mulsant \& Rey, 1864. Dead trees with $F$. pinicola were abundant also at one site in Latvia where Dorcatoma janssoni was found (Jansson pers.comm.).

Within the genus Dorcatoma, only $D$. chrysomelina and D. flavicornis (Fabricius, 1792) are also known to develop in wood that is decomposed by fungus mycelia. These two species are bound to the fungus Laetiporus sulphureus, which grows on most species of decidous trees and is especially abundant on willow (Salix sp.) and oak (Quercus sp.). 


\section{Key to European Dorcatoma-species with erect and dual pubescence (chrysomelina-group).}

Illustrations of the male genitalia for the species not figured in this paper are found in Baranowski (1985), Español (1978), and Jonsell (1998). Biological notes are mainly according to Neumann \& Büche (1998).

1. Body length 1.6 to $2.7 \mathrm{~mm}$, body black or nearly so in fully coloured specimens. Whole Europe ................. 2

- Body length 2.5 to $3 \mathrm{~mm}$, body light brown. Species of Mediterranean distribution ....................................... 8

2. Punctation of dorsal and ventral surface dual, composed of fine and larger punctures that are not intergrading in size on the elytra. Larger punctures usually elliptic on the elytral disk.

- Punctation of dorsal surface uniform, punctures circular; sometimes not exactly equal in size, but intergrading

3. Elytra with the two lateral striae of the same length, nearly reaching the suture at the apex. The subhumeral striae clearly impressed in the basal third of the elytra (but often interrupted). Antennal segment 4 not different from segments 3 and 5. Median furrow of the metasternum complete

4

- Elytra with the two lateral striae not of the same length, the inner one absent near the suture. The subhumeral striae much shorter or reduced to inconspicuous series of coarse punctures. Antennal segment 4 pointed inside, much broader than segments 3 and 5. Median furrow of the metasternum incomplete, effaced in the posterior third

4. Punctation of dorsal surface dense, more or less rugose. Elytra more or less dull due to wrinkly microsculpture, visible on the whole surface. For safe recognition, male genitalia should be examined (Fig. 4).

chrysomelina Sturm

- Punctation of dorsal surface less dense, punctures usually separated from each other. Elytra with the microsculpture often confined to sutural area, dorsal surface more shiny. For safe recognition, male genitalia should be examined (Fig. 2a, b). janssoni n.sp.

5. Dorsal surface shiny, punctation fine. Subhumeral striae feebly indicated by series of coarse punctures. Antennae short and very similar in both sexes. Male genitalia, see Fig. 5. Larvae have been found in Fomes fomentarius and Ganoderma sp. androgyna Büche

- Dorsal surface dull due to coarse and dense punctation. Subhumeral striae impressed, but visible in the basal fifth of the elytra only. Male antennae with the terminal segments strongly enlarged. Larval development observed

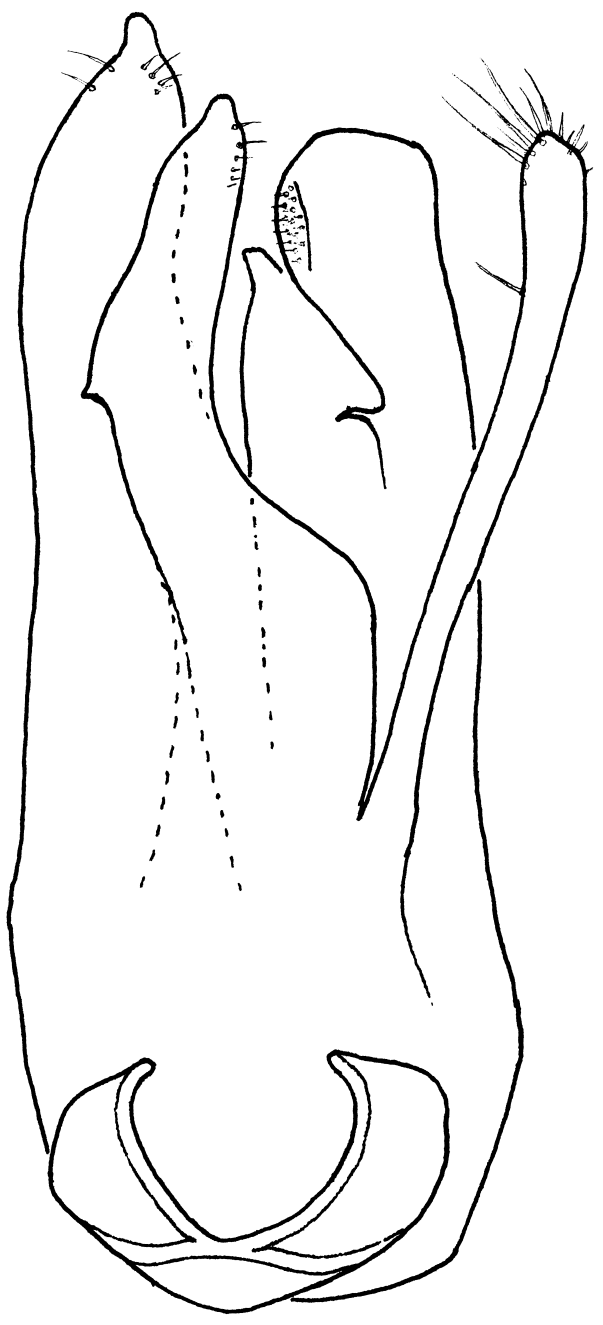

Fig.4. Dorcatoma chrysomelina: Aedeagus, dorsal view.

in Inonotus cuticularis. ............. ambjoerni Baranowski

6. Pubescence on the elytra arranged in ten regular, longitudinal bands. Metasternum at center with loose, but dual punctation, its median furrow effaced posteriorly. Larvae develop in several species of Phellinus. ......................... setosella Mulsant \& Rey

- Pubescence on the elytra uniformly distributed or arranged in confused bands. Metasternum at center with dense and uniform punctation, its median furrow complete.....

7. Pubescence on the elytra uniformly distributed, moderately erect (about $45^{\circ}$ ). Body finely punctured. Terminal segment of maxillary palpi with sides parallel in apical 


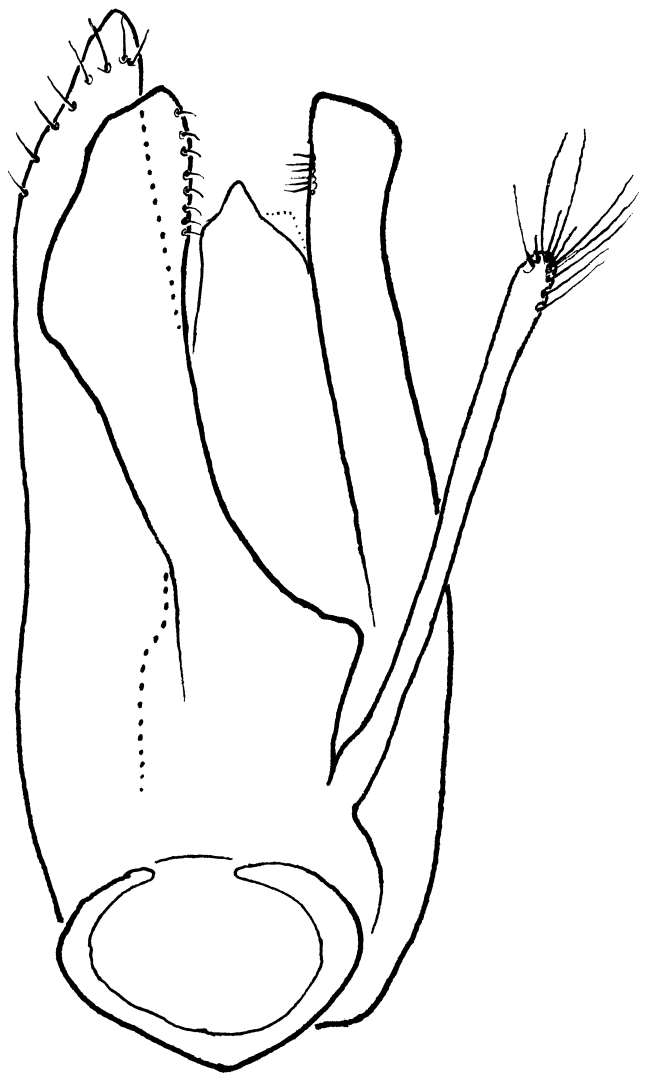

Fig.5. Dorcatoma androgyna: Aedeagus, dorsal view.

half. Larval development in various fungi, species of Inonotus are preferred................... substriata Hummel

- Pubescence on the elytra arranged in confused bands, erect (about $75^{\circ}$ ). Body punctation stronger. Terminal segment of maxillary palpi triangular. Larvae develop in Fomes fomentarius. .................... minor Zahradnik

8. Terminal segment of maxillary palpi triangular, antennal segment 8 deeply emarginate in the male. Sardinia, Italy, France. lanuginosa Baudi

- Terminal segment of maxillary palpi elongate, rather parallel-sided; antennal segment 8 feebly emarginate in the male. Spain. vaulogeri agenjoi Español

Acknowledgments. Rickard Andersson, Mats Jonsell, Henrik Wallin and Petr Zahradnik have studied material and expressed their opinion. We are especially grateful to Nicklas Jansson and Pär Eriksson for material of the new species, comments and field assistance, and to Keith Philips for linguistic comments. The investigation in the Vällen- area in Sweden, which produced most specimens, was carried out by the Uppland foundation with economical support from EU/Life-fund.

\section{References}

Baranowski, R. 1985: Central and Northern European Dorcatoma (Coleoptera: Anobiidae), with a key and description of a new species. - Ent. Scand. 16: 203207.

Borowski, J. 1999: A contribution to the Central European species of the genus Dorcatoma Herbst, 1792 (Coleoptera, Anobiidae, Dorcatominae). - Ann. Warsaw Agricult. Univ. SGGW, For. and Wood Technol. 49: $127-136$.

Büche, B. 2001: A new fungivorous Deathwatch-beetle from Europe (Coleoptera, Anobiidae). - Entomologische Blätter 96(3): 229-234.

Español, F. 1977: Notas sobre Anóbidos (Col.) 76. Avance al estudio de la sección Dorcatoma. - Miscelánea Zoológica (Barcelona) 4(1): 184-215.

Español, F. 1978: Sobre algunos Dorcatoma del Mediterráneo occidental (Col. Anobiidae, Nota 86). — Miscelánea Zoológica (Barcelona) 4(2): 77-85.

Hayashi, N. 1954: Taxonomic notes on Japanese species of the genus Dorcatoma, with descriptions of three new species. - Insecta Matsumurana 18: 87-93.

Jonsell, M. 1998: En ny tickgnagere i Sverige, Dorcatoma minor Zahradnik (Coleoptera: Anobiidae) och dess värdval. — Ent.Tidskr. 119(2): 105-109.

Logvinowskij, V. D. 1980: A review of the genus Dorcatoma Herbst (Coleoptera, Anobiidae) in fauna of the USSR. — Entomologiskoje Obozrenje 59: 148153. [In Russian.]

Mulsant, E. \& Rey, C. 1864: Histoire Naturelle des Coléoptères de France. Térédiles. - F. Savy, Paris. $391 \mathrm{pp}$.

Neumann, C. \& Büche, B. 1998: Dorcatoma minor Zahradnik 1993 (Coleoptera: Anobiidae) - Anmerkungen zur Bestimmung, Verbreitung und Biologie auch der verwandten Arten. - Mitteilungen des Entomologischen Vereins Stuttgart 1869 e. V. 33: 67-71.

White, R. E. 1966: Six new Anobiidae from North America with keys. - Proc. Ent. Soc. Wash. 68: 228-236.

Zahradnik, P. 1993: New species of the genus Dorcatoma from Central Europe (Coleoptera, Anobiidae). — Folia Heyrovskiana 1: 80-83.

Zahradnik, P. 1996: Four new species of Anobiidae (Coleoptera) from Turkey and Rhodes Island. — Folia Heyrovskiana 4(3): 93-101.

Zahradnik, P. 1998: Anobiidae of Turkey (Coleoptera). Klapalekiana 34: 263-286. 